daily by Mr. Buchanan; and during the trip Mr. Buchanan has determined the amount of carbonic acid in 25 different samples-i 5 from the surface, 7 from the bottom, and 2 from intermediate depths. The smallest amount of carbonic acid was found in surface-water on Jan. 27, near Kerguelen; it amounted to 0.0373 gramme per litre. The largest amount, 0.0829 gramme per litre, was found in bottom-water on Feb. I4, when close to the Antarctic ice. About the same latitude the amount of carbonic acid in surface-water rose to the unusual amount of 0.0656 gramme per litre; in all other latitudes it ranged between 0.044 and 0.054 gramme per litre. From the greater number of these samples the oxygen and nitrogen were extracted, and sealed up in tubes.

"While we were among the ice all possible observations were made on the structure and composition of icebergs. We only regretted greatly that we had no opportunity of watching their birth, or of observing the continuous ice-barrier from which most of them have the appearance of having been detached. The berg- and floeice was examined with the microscope, and found to contain the usual Diatoms. Careful drawings of the different forms of icebergs, of the positions which they assume in melting, and of their intimate structure, were made by Mr. Wild, and instantaneous photographs of several were takcn fiom the ship.

"I need only further add that, so far as I am able to judge, the expedition is fulfilling the object for which it was sent out. The naval and the civilian staff seem actuated by one wish to do the utmost in their power, and certainly a large amount of material is being accumulated.

"The experiences of the last three months have, of course, been somewhat trying to those of us who were not accustomed to a sea-life ; but the health of the whole party has been excellent. There has been so much to do that there has been little time for weariness; and the arrangements continue to work in a pleasant and satisfactory way."

\section{COLONIAL GEOLOGICAL SURVEYS}

\section{I.- CANADA}

\section{Report of Geological Survey of Canada for $1872 \cdot 73$.}

1 ATHER less than thirty years ago the Canadian 1 Legislature passed a vote for the institution of a Geological Survey of the province, with the object of ascertaining definitely the mineral resources of the country. In pursuance of this decision, the Governor-General, after some inquiry about a properly qualified individual to take charge of the Survey, finally appointed Mr. W. E. Logan, who, born in Canada, had made his name known in England by some careful surveys of the South Welsh Coalfield, and by original observations on the origin of coal. For thirty long years of unremitting labour, with obstacles of every kind, physical, pecuniary, political, the brave and sagacious director stuck to his post. Many a time with a legislature impatient for practical results in the discovery of minerals, and a ministry indifferent to science and bent on popularity by retrenchment of the budget, the chances of the Canadian Survey seemed desperate. But the pilot who guided its destinies showed himself as shrewd a judge of men, and as able to win them over, as he was a skilful pioneer in geology. And the result is that he has made the Canadian Geological Survey one of the first in the wor'd, excellent in its equipment, considering the slender means placed at his disposal, and altogether admirable for the vast amount of solid work which it has accomplished-work which has not merely been of service to Canada, but has acquired a world-wide interest. In doing this he has made his own name a household word among geologists of every country. Canada may well be proud of her Sir William Logan.

About four years ago, having toiled so long and hard, he felt compelled to relinquish his post and seek the rest which his old age so needed and deserved. He was succeeded by Mr. Alfred R. Selwyn, who had been trained in the early days of the Geological Survey under Sir Henry De la Beche, had done much excellent and difficult geological work in Wales, and had thereafter held for a number of years the post of Director of the Geological Survey of Victoria. The Victorian authorities in 1869 suppressed their survey. When Mr. Selwyn lost that appointment, he was induced to accept the guidance of the establishment in Canada. There could hardly have been found a fitter successor to Sir William Logan. Long experience in all the details of geological surveying, both in civilised and in still unexplored regions, must have made it an easy matter for Mr. Selwyn to adapt himself to Canadian modes of exploration. He was renowned in his old Welsh days for his prowess as a mountaineer, and to judge from the present report the advance of years has not perceptibly impaired his bodily activity and powers of endarance. During the comparatively brief season when geological reconnaissances are possible in British North Amcrica he is found at one time away in the far east of the dominion inspecting mines in Nova Scotia, at another time with his colleagues and Indians laboriously toiling through river, lake, and portage, in the still only partially explored regions towards Fort Garry, or camping out for many weeks on the shores of Lake Superior. During 1872 the operations of the Canadian Survey under his charge extended across the whole breadth of North America at its broadest part, that is from the Queen Charlotte Islands to the headlands of Nova Scotia-a distance, in a straight line, of considerably more than 3,000 miles.

The success of such a service as that of the Canadian Geological Survey must depend, however, in large part on the calibre of the men who act under the director. And Mr. Selwyn is fortunate in his staff, which is nearly the same as that under Sir William Logan. Of his explorers in the field Mr. R. Bell and Mr. James Richardson have done much of that sound work on which the reputation of the Canadian Survey rests. To Mr. Billings, who determines his fossils, and to Dr. Dawson, who, though not attached to the Survey, generously lends his assistance in the palæentological department, the Survey is likewise largely indebted. As an analyst of minerals and ores and an able writer on chemical geology Sir William Logan had a tower of strength in Dr. Sterry Hunt, who has lately accepted an appointment in the United States. Dr. Hunt's successor, Dr. Harrington, carries with him into his new duties the good wishes of all geologists who take 
interest in the pursuit of mineralogy and petrography and in the perplexing problems of metamorphism. One of the oldest and best of Sir William's staff, Mr. Murray, has now an independent sphere of work in Newfoundland. He has issued a number of reports, to which and to his other services we shall return on a future occasion.

Geological field-work in Canada differs very markedly from field-work in most other countries. Iriost of the districts over which the Survey is now extending are in great measure, or wholly, unexplored, some of them, indeed, having never been visited by a white man before the adventurous geologist attacked their rocks with his hammer. There being no roads, and the country thickly timbered, the rivers form the natural routes for exploration. Each member of the staff receives in the early summer his instructions as to the area to be surveyed during the five or six months at most when surveying is possible. Providing himsclf with birch-bark canoes, two or more white men as voyageurs, and a variable band of Indians as guides and portage carriers, likewise with provisions for the entire party for the whole stason during which the tour is to last, he starts on his voyage of discovery. Of course in such regions he has either no map at all or some mere rough sketch, so that he needs to construct the topography as well as the geology of his charts. Ascending the river which has been chosen, the party halts each night at some favourable creek and sleeps under cloaks or skins upon the shore. Sir William Logan used to sleep in a sack on the beach of Lake Superior, with his head stuck out of the mouth of it, and after tucking himsclf in would sometimes need to creep out again to knock off the edge of some protuberant rock, and thus literally to smooth his bed with his hammer. Expertness as a shot forms a valuable qualification in one of these explorers, and enables himself and his comrades now and then to enjoy the luxury of fresh meat. Great trouble often arises with the Indian attendants. Sometimes they cannot be had at all, and when obtained are apt to clepart at a moment's notice, leaving the white men to manage their journey as they best can.

The Report of the Canadian Survey for $1872-73$ bears the stamp of the same thorough unostentatious work which has characterised the whole of the long series of Reports from 1843 downwards. In such a yearly summary of progress we cannot expect the completeness of a finished memoir. The observers merely chronicle what they have seen in the tracts visited by them. But on this account their Reports are probably all the surer an index to their powers of rapid observation and of grasping main features of geological structure. In this aspect Mr. Richardson's Report, On the coalfields of Vancouver and Queen Charlotte Islands, deserves high commendation. By the time he could get himself transported across the continent to San Francisco, and thence by steamer to the part of Vancouver Island where his explorations were to be made, it was the beginning of July, and the heavy rains began before the end of September. In spite of wind and wet, however, he stuck to his work, and after storing away his boat, tent, and camp-equipage for next year's service, set out once more on his long journey, and reached Montreal in the middle of December. During these few and interrupted months he added considerably to what was previously known regarding the secondary coalfields of that part of America, made a number of careful measurements of the thicknesses of the strata, and brought home many fossils, both plant and animal, new to science.

He found that the coal-bearing rocks lic upon a vast depth of older crystalline masses among which he detected fossiliferous limestones. This metamorphosed series he estimates at somewhere about 17,000 ft. in thickness. When the fossils were submitted to Mr. Billings, that able palreontologist found them too obscurely preserved to warrant a definite opinion as to their age. From his reference of some of the corals to such genera as $Z a p h$ rentis, and theoccurrence of Productus, Spirifer, and Fenestella, the rocks would at ieast seem to be certainly Upper Palæozoic, though he does not go further than to suggest that they may be "either Permian or Carboniferous, more probably the latter." On this great metamorphic group the coal-bearing rocks rest unconformably. To these rocks Mr. Richardson assigns a thickness of 5,000 ft. They consist of various shales, sandstones, shell-bearing limestones, and conglomerates with intercalated seams of coal, very mucl resembiing apparently some parts of our Carboniferous sections in Britain. Their geological position appears to be about the parallel of our Cretaceous and perhaps the upper part of our Jurassic series. Among the plants Dr. Dawson finds some forms of cypress and yew, cycads and ferns, with species of oak, birch, and poplar, and remarks that these fossils furnish additional evidence of a fact already noticed, "that in the Cretaceous period the generic types of American trees were as well marked as at present." Among the shells, Mr. Billings finds 16 species of Ammonites, 2 of Belemmites, a Nautilus, 4. Gasteropods, and 9 genera of Lamellibranchs, the general facies of the whole being decidedly Cretaceous and Upper Jurassic. He admits the view of the States geologists to be substantially correct, that the coal of Vancouver Island belongs to one of the Cretacous groups which is developed in northern California and Oregon. At the same time the rossil evidence suggests that while the Vancouver beds may be Upper Cretaceous, those of the Queen Charlotte Islands are partly Lower Cretaceous and partly Upper Jurassic. From the fact that the fossils in the Cretaceous formations on the west side of the Rocky Mountains are specifically different from those on the east side, Mr. Billings suggests the former existence of a land-barrier down the American continent on which the abundant Cretaceons flora flourished.

The route followed by Mr. Bell, of which an account is given in this Report (On the country between Lake Superior and lake Winnipeg), presented comparatively little of general interest, though it gave scope for the same methodical and careful work for which his previous reports are distinguished. One fact deserves notice among his remarks, namely, that he has confirmed his previous observations of a great conformable series of metamorphosed Huronian rocks resting upon the Lat1rentian gneiss. Mr. Selwyn suggests that the conformability may be only local and deceptive. This is certainly a matter deserving attentive examination. Mr. McOuat contributes a well-written Repori on the colintry between Lakes Temiscamang and Abbitibbe, where he was busy tracing the relations of some of the metamorphic rocks there to those on Lakes Huron and Superior. Mr. Ven- 
nor's Report deals with a more civilised part of the country, which had already, to some extent, been examined by the Survey. He is evidently an accession of great strength to the staff.

While explorations were in progress on the shores of the Pacific among the Vancouver coalfields, other members of the Survey were busy on the Atlantic borders among the coalfields of New Brunswick and Nova Scotia. Prof. Bailey and Mr. Matthews have written a valuable account of the New Brunswick region, which it is to be hoped will be extended and published with sections and fuller details. Several other Reports are included in the volume, having more of a practical than a scientific interest. In fine; the Geological Survey of Canada may be congratulated upon the evidences of continued activity which this volume furnishes. The form of such Annual Reports necessarily precludes a systematic treatment of the subject, and makes it somewhat difficult for readers unfamiliar with the localities to grasp the main features of geological importance amid the manifold local details. It is earnestly to be wished, therefore, that before many years pass away another general volume may be issued like that which Sir William Logan published eleven years ago.

ARCh. GEIKIE

(To be continued.)

\section{OUR BOOK SHELF}

\section{Field Ornithology. By Dr. Elliot Coues. (Naturalists' Agency, Salem.)}

OUR ornithological readers are all familiar with $\mathrm{Dr}$. Coues' excellent "Key to North American Birds," which we noticed on its appearance. In that work it was intended that instruction in the best means of collecting and preserving birds should have been incorporated, which was prevented by the unexpected dimensions which the volume assumed. The same author now gives us these important instructions in a separate small manual, with whioh he combines a check list of the species described in the "Key," arranged in accordance with his own views, as a supplement to the larger work. The subjects treated of will be found of great service to all collectors, especiaily to those, both amateur and professional, who are commencing to attempt the accumulation and the preservation of bird-skins. The hints on the selection of a gun, shot, \&c., will be of especial service to all sportsmen of small game, whilst the carefully-written account of the best way in which the skinning of birds, both large and small, should be undertaken, will well repay the perusal, even of the experienced. The various less well-known means of preserving specimens, as in spirit, and by means of carbolic acid, which latter is not inaptly termed by the author "mummification," are described in detail. Of the carbolic-acid method it is remarked: "I mention the process chiefly to condemn it as an atrocious one; I cannot imagine what circumstances would recommend it, while only an extreme emergency could justify it. It is further objectionable because it appears to lend a dingy hue to some plumages, and to dull most of them perceptibly." Notwithstanding these disadvantages there is one point which recommends this process, it being that the bodies of the birds preserved by it are in a condition quite fit for the dissection of the muscles and other organs, after they have been soaked for some time. Nothing is more diffcult than for the students of internal structure to get most of the bodies of which they despondently regard so many skins; and they naturally look with delight at any method which gives them a chance of obtaining the species they desire. The check list will be found of much use to those who collect the birds of North America. It is printed on one side of the page only, and separate copies are to be printed, which can be cut up for cabinet purposes. For those who are commencing ornithology practically we know no book which will prove so serviceable as Dr. Coues' little work.

\section{LETTERS TO THE EDITOR}

[The Editor does not hold himself responsible for opinions expressed by his correspondents. No notice is taken of anonymous communications.]

\section{Proposed Issue of Daily Weather Charts of Europe} and the North Atlantic

I IIAve the honour to inform you that Capt. Hoffmeyer, Director of the Royal Meteorological Institute of Copenhagen, has sent me a circular announcing his intention to publish daily charts of the weather for the district from $60^{\circ} \mathrm{E}$. to $60^{\circ} \mathrm{W}$. long. and from $30^{\circ}$ to $75^{\circ} \mathrm{N}$. lat. The charts for the three monthsDec. $1873-\mathrm{Feb}$. I $874-$-will be published as an experiment.

The cost will be four francs per month, exclusive of postal charges.

Capt. Hoffmeyer states that he can only deal with central offices, and has requested me to undertake these islands as regards the distribution of the charts. I have therefore to announce that I have been instructed by the committee to subscribe for twentyfive copies of these charts, and I shall be happy to supply copies for the three months to any gentleman, at the cost of ris. to cover carriage from Copenhagen, and postage from London to his address.

Meteorological Office, June 22

\section{The Degeneracy of Man}

Dr. OSCAR PESChel, in his recently published "Völkerkunde" (p. 137), calls attention to a remark by the late Dr. von Martius, of much interest to anthropoiogists. It is well known that this distinguished naturalist avowed in the strongest terms his belief that the savage tribes of Brazil were the fallen descendants of more cultured nations. In 1838 he said :- " Every day I spent among the Indians of Brazil increased my conviction that they had once been in quite another state, but that in the lapse of dark ages there had broken in upon them manifold cata. strophes, which had brought them down to their actual condition, that of a peculiar decline and degeneration. The Americans are not a wild race, they are a race run wild and degraded." To students of civilisation (myself for example) Dr. Martius' views have been most embarrassing. It was not strange that the theory of savages being the degraded offspring of primeval civilised men should have been advocated by Archbishop Whately, who did not even take the trouble to examine his own evidence. Nor is it surprising that the Bishop of Ely, in the "Speaker's Com. mentary," should still appeal to Whately as an unrefuted authority, for one hardly expects an orthodox commentator to test the arguments on his own side. But the case with Dr. Martius was quite different. HXere was an eminent ethnologist, intimateiy acquainted with savage thought and life, declaring that it seemed to him not to indicate natural wildness, but to show traces of decay from an ancient higher culture. What made the malter more puzzling, was that Dr. Martius, in his researches, had come upon facts which he acknowledged to be evidence of progress taking place from savage toward civilised institutions. Thus, among the forest tribes of Brazil he found the rudest form of the "village community," with its tribe-land common to all, but the huts and patches of tilled ground treated as acquired private property, not indeed of individuals, but of families. It was manifest that these tribes were passing through stages of that very development of the law of real property which is so clearly shown in the history of European law. This is a strong argument in favour of the development-theory of civilisation, but how could an ethnologist who understood the force of such arguments, remain an upholder of the degeneration-theory?

Dr. Peschel considers that he did not so remain, but had changed his opinion when, nearly thirty years later, he wrote as 